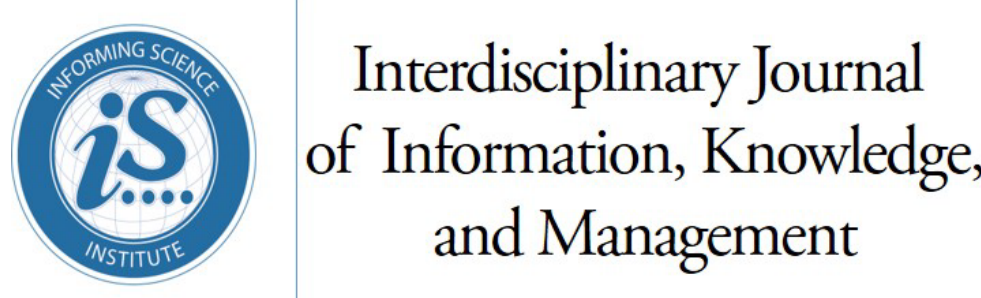

An Official Publication

of the Informing Science Institute

InformingScience.org

IJIKM.org

Volume 16, 2021

\title{
The NeXus BETWEEN LEARNING ORIENTATION, TQM PraCtices, INNOVATION CULTURE, AND Organizational Performance of SMEs in KuWait
}

$\begin{array}{cl}\text { Fahad Awad Aber Sawaean* } & \begin{array}{l}\text { National University of Malaysia, } \\ \text { Malaysia. }\end{array} \\ \text { Khairul Anuar Mohd Ali } & \begin{array}{l}\text { National University of Malaysia, } \\ \text { Malaysia }\end{array} \\ * \text { Corresponding author } & \end{array}$

V fahad@hotmail.com

kabma@ukm.edu.my

\begin{abstract}
Aim/Purpose

This paper aimed to examine the impact of learning orientation on organizational performance of small and medium enterprises (SMEs) via the mediating role of total quality management (TQM) practices and the moderating role of innovation culture.

Background

SMEs' organizational performance in developing countries, particularly in $\mathrm{Ku}$ wait, remains below expectation due to increasing competition and inadequate managerial practices that negatively impact their performance. Although several studies had revealed a significant effect of learning orientation on SMEs' performance, the direct impact of learning orientation on their performance is still unclear. Thus, the link between learning orientation and organizational performance remains inconclusive and requires further examination.

Methodology This study adopted a quantitative approach based on a cross-sectional survey and descriptive design to gather the data in a specific period. The data were collected by distributing a survey questionnaire to the owners and Chief Executive Officers (CEOs) of Kuwaiti SMEs using online and on-hand instruments with 384 useable data obtained. Furthermore, the partial least square-structural equation modeling (PLS-SEM) analysis was performed to test the hypotheses.

Contribution

This study bridged the significant gap in the role of learning orientation on SMEs' performance in developing countries, specifically Kuwait. In this sense, a conceptual model was introduced, comprising a learning orientation, TQM practices, innovation culture, and organizational performance. In addition, this
\end{abstract}

Accepting Editor Nelson K. Y. Leung | Received: November 22 2020| Revised: February 6, March 3, March 31, April 1, 2021 | Accepted: April 2, 2021.

Cite as: Sawaean, F. A. A., \& Ali, K. A. M. (2021). The nexus between learning orientation, TQM practices, innovation culture, and organizational performance of SMEs in Kuwait. Interdisciplinary Journal of Information, Knowledge, and Management, 16, 147-172. https://doi.org/10.28945/4743

(CC BY-NC 4.0) This article is licensed to you under a Creative Commons Attribution-NonCommercial 4.0 International License. When you copy and redistribute this paper in full or in part, you need to provide proper attribution to it to ensure that others can later locate this work (and to ensure that others do not accuse you of plagiarism). You may (and we encourage you to) adapt, remix, transform, and build upon the material for any non-commercial purposes. This license does not permit you to use this material for commercial purposes. 
Findings

Recommendations for Practitioners

Recommendations for Researchers

Impact on Society

Future Research

Keywords study confirmed the significant influence of TQM practices and innovation culture as intermediate variables in strengthening the relationship between learning orientation and organizational performance, which has not yet been verified in Kuwait.

The results in this study revealed that learning orientation had a significant impact on organizational performance of SMEs in Kuwait. It could be observed that TQM practices play an important role in mediating the relationship between learning orientation and performance of SMEs, as well as that innovation culture plays an important moderating role in the same relation.

This study provided a framework for the decision-makers of SMEs on the significant impact of the antecedents that enhanced the level of organizational performance. Hence, owners/CEOs of SMEs should improve their awareness and knowledge of the importance of learning orientation, TQM practices, and innovation culture since it could significantly influence their performance to achieve success and sustainability when adopted and managed systematically. The CEOs should also consider building an innovation culture in the internal environment, which enables them to transform new knowledge and ideas into innovative methods and practices.

The results in this study highlighted the mediating effect of TQM practices on the relationship between learning orientation (the independent variable) and organizational performance (the dependent variable) of SMEs and the moderating effect of innovation culture in the same nexus. These relationships were not extensively addressed in SMEs and thus required further validation.

This study also influenced the management strategies and practices adopted by entrepreneurs and policymakers working in SMEs in developing countries, which is reflected in their development and the national economy.

Future studies should apply the conceptual framework of this study and assess it further in other sectors, including large firms in developing and developed countries, to generalize the results. Additionally, other mechanisms should be introduced as significant antecedents of SMEs' performance, such as market orientation, technological orientation, and entrepreneurial orientation, which could function with learning orientation to influence organizational performance effectively.

small and medium enterprises, learning orientation, total quality management practices, innovation culture, organizational performance, resource-based view, Kuwait

\section{INTRODUCTION}

The role of small and medium enterprises (SMEs) in the economic development of industries and developing countries is of critical significance (Manzoor et al., 2019). Globally, SMEs' role is one of the main instruments for economic independence (Hoque \& Awang, 2019). In general, SMEs promote sustained development objectives by creating employment opportunities, promoting entrepreneurship and innovation activities, endorsing sustained industrialization, and narrowing income disparities, which are essential to eradicate poverty in developing nations (Manzoor et al., 2019).

Over the last few years, most businesses operating in Kuwait are SMEs (Alzougool, 2019). Despite the magnanimous economic support and contribution of the governments in developing countries 
towards improvement of SMEs sector, SMEs' performance in developing countries fall short of the governments expectations in strengthening the national economy (Afriyie et al., 2019; AlQershi et al., 2020; Hafeez et al., 2013; Haroon \& Shariff, 2016; Lo et al., 2016; Mgeni, 2015; Peter et al., 2018). Similarly, in Kuwait, SMEs' contribution to its GDP is low at 3\%, indicating its SMEs' weak performance compared to other developing economies (Abu-Aisheh, 2018; Al-duwailah et al., 2019; Alzougool, 2019). Furthermore, SMEs in Kuwait contribute only $23 \%$ of the total employment, which is two times less than the percentage of SME employment in developed economies (Abukumail et al., 2016; Al-duwailah et al., 2019; Alzougool, 2019). This situation indicates poor growth and a high failure rate in Kuwaiti SMEs.

This weak performance is due to the country's lack of appreciation of SMEs' critical role in the national economy (Abu-Aisheh, 2018). Therefore, Kuwait has recently established government agencies to support the SME sector and help entrepreneurs enhance their firms' performance to maximize their economic contribution (Miniaoui \& Schilirò, 2017; Ramadhan \& Girgis, 2018). Despite the recent entrepreneurial strategies adopted by Kuwait and the continuous efforts to improve SMEs' performance, SMEs and entrepreneurs still face numerous challenges (Abu-Aisheh, 2018; Alhabashi, 2015; Dana et al., 2021). Therefore, these issues must be identified and resolved so that SMEs could become a major contributor to Kuwait's economic development.

In order to understand what weakens SMEs' performance, many researchers have attempted to study various factors and predictors in creating efficient models to ensure continuous improvement of SMEs' performance, such as entrepreneurial leadership (Nor-Aishah et al., 2020), customer relationship management (CRM) (AlQershi et al., 2020), technological capabilities (Taghizadeh et al., 2020), knowledge management (Ferraris et al., 2019), entrepreneurial and market orientation (Mamun et al., 2018), and supply chain network (Z. Ali et al., 2019). Although they have provided important insights, there were inconsistent results on the strength and direction of the relationships. In fact, no systematic literature had presented an in-depth understanding of the variables affecting the SMEs' ability to increase their performance. Due to this critical gap, the current study analyzed the existing knowledge on the predictors of SMEs' performance to create new models and develop theories and dependable recommendations for effective management practices.

According to, Resource-Based View (RBV) theory, SMEs will not achieve a superior competitive edge and performance relative to their competitors by prioritizing their tangible assets without scrutinizing and optimally harnessing their internal and intangible resources (Ratnawati et al., 2018). SMEs in the contemporary business environment must deal with intense competitive pressure. Therefore, SMEs must enhance their competitive abilities to ensure their survival and sustained development. There are several approaches and strategies that SMEs can adopt to deal with continuous changes and threats that could improve their performance and achieve sustainability (Yang, 2018). The organizational learning theory proposed that SMEs can enhance their performance and capacity by exploring and integrating new knowledge with their existing knowledge (Huang \& Li, 2017). Learning orientation is crucial for organizations that should take suitable actions to adapt to the changing technology, customer demands, and multifaceted environment in order to improve overall performance (Harvey et al., 2019).

In principle, learning orientation is an organization's commitment and passion in enhancing an individual's potential, knowledge, competency, and skills (Atitumpong \& Badir, 2018). Beneke et al. (2016) defined learning orientation as the fundamental values, beliefs, and practices that shape an organization's ability to acquire, assess, share, and implement knowledge and information regarding technological advancements, customer requirements, competitors, and changes in the marketplace. Furthermore, learning orientation helps organizations create novel mental models and surpass the learning frontier by exploring new methods to interpret, exploit, and translate knowledge into wellorganized practices and processes (Huang \& Li, 2017). Learning orientation also aims for structure transformation, which focuses on articulating change in an organization through continuous improvement (Mahmood et al., 2015). Thus, the extent to which learning orientation can improve 
SMEs' performance depends on other organizational factors including total quality management (TQM practices) that ensure continuous improvement of the whole organization.

TQM is an integrated managerial philosophy that aims to continuously improve the quality of processes and goods to achieve customer satisfaction and better organizational performance (Anil \& Satish, 2016). Mehra and Rhee (2004) asserted that TQM practices are a powerful management instrument in enhancing the learning process through emphasizing teamwork and cooperative learning. Moreover, several researchers have confirmed that implementing TQM practices could increase SMEs' flexibility, efficiency, and competitiveness to fulfil customer requirements and enhance organizational performance by continually improving their activities (Imran et al., 2018; Mehralian et al., 2017; Pambreni et al., 2019; Yang, 2018). Hence, integrating learning orientation with TQM practices could significantly affect SMEs' performance if accompanied by innovation culture, which creates common individual beliefs, values, and assumptions that facilitate the innovation process and enhance organizational performance (Dabić et al., 2018).

There is an uncertainty in the literature review concerning the effect of learning orientation on SMEs' performance (Beneke et al., 2016; Wolff et al., 2015). Hence, this study bridged the significant literature gap in developing countries by investigating the impact of learning orientation on SMEs' organizational performance with TQM practices and innovation culture as intermediate variables. This study is also one of the few conducted in emerging economies that investigated the effect of these variables in one model. Past studies have proposed that managerial issues are among the primary factors connected to SMEs' failure in developing countries (Abdollahi et al., 2014; Haroon \& Shariff, 2016). In this regard, SMEs' managers still struggle to deal with incompetent managerial activities that require effective managerial practices, sufficient knowledge of the principles of quality, and innovation process, all of which significantly affect their businesses development. In light of this, the present study revealed multifaceted theoretical and practical solutions by increasing SME managers' awareness in developing countries about the significance of the complementary roles of learning orientation, TQM practices, and innovation culture. These practices enable organizations to improve their organizational performance when adopted systematically.

\section{LITERATURE REVIEW}

\section{ORgANIZATIONAL PERFORMANCE}

The potential success of any organization, including SMEs in developing countries, depends on its organizational performance ( $\mathrm{Ng} \& \mathrm{Kee}, 2018)$, capacity to effectively implement activities and strategies, and the efforts toward achieving its objectives (AlQershi et al., 2020). Due to this fact, organizational performance is one of the most controversial concepts among scientists in establishing the effective factors that contribute to continuous performance improvement (Carter et al., 2018). The definitions of organizational performance vary, similar to its differing philosophies. Richard et al. (2009) defined organizational performance as an organization's actual output compared to its expected outputs (goals and objectives).

Moreover, organizational performance is described as the sum of activities and achievements attained by all departments within a given period (Kamau \& Wanyoike, 2019). Z. Ali et al. (2019) defined organizational performance as an organization's effective transformation of tangible and intangible resources to achieve its objectives. Therefore, organizational performance is the productivity of its firm members determined by their revenue, earnings, development, and growth.

It could be observed that several studies have provided significant outcomes in enhancing SMEs' performance in developing countries (Alosani et al., 2020; Bahta et al., 2020; Eniola et al., 2019; Kiyabo \& Isaga, 2019). However, few studies provide effective antecedents, variables, and models that impact SMEs' performance, leading to their weak performance in developing countries (G. Ali et al., 2020), particularly in Kuwait (Abu-Aisheh, 2018; Al-duwailah et al., 2019; Alzougool, 2019). SMEs in 
developing countries strive to obtain a superior competitive advantage in the national market due to competition from international firms to remain profitable and increase their performance. Nevertheless, limited studies have identified the factors and variables that contribute to developing SMEs' performance in emerging economies (Bannour \& Mtar, 2019; Rojas-Lema et al., 2020).

As mentioned in the contingency theory, there is no performance measuring system and framework useable for all types of organizations under all conditions; contrarily, the systems are adapted based on the established organizational and context-specific factors (Richard et al., 2009). Therefore, business models related to SMEs should be extended by exploring specific competencies that enhance SMEs' performance continuously (Falahat et al., 2020). In this vein, Asemokha et al. (2019) stated that issues related to organizational learning, managerial activities, innovation culture, and other drivers that affect SMEs' sustainability and growth remain unresolved. Hence, the elements that increase SMEs' performance at all firm levels remain largely unexplored (Kafetzopoulos, 2020).

In general, past studies have developed multifaceted models to measure the effect of different variables such as learning orientation (Atitumpong \& Badir, 2018; Harvey et al., 2019; Kiyabo \& Isaga, 2019), TQM practices (Al-Dhaafri et al., 2016; Eniola et al., 2019; Qasrawi et al., 2017), and innovation culture (Dabić et al., 2018; Xie et al., 2016) on SMEs' performance. Literature reviews have shown contradicting results on the critical roles of the variables on improving the SMEs' performance directly. Furthermore, some studies have failed to confirm the role of learning on their performance (Beneke et al., 2016; Wolff et al., 2015). Meanwhile, other studies have not found any significant impact of TQM practices in terms of involvement of people, customer focus, leadership, and continual improvement components on SMEs' performance (Sinha et al., 2016). Hence, more studies should measure the impact of TQM practices on SMEs' performance and should not stop with the results extracted from studies applied on large firms (Sahoo \& Yadav, 2020; Sila, 2018). Studies have also suggested that innovation culture does not directly affect their performance and should play a conditional role (Ghasemzadeh et al., 2019).

Based on the literature review, researchers noted a lack of rigorous models with a continuous role in enhancing performance due to the different contexts in which these models were applied. The performance cannot be systematically managed without understanding the context and antecedents of SMEs. Hence, the set of variables and models should be improved and extended to offer more insights into SMEs' growth in developing countries (Kafetzopoulos, 2020). Therefore, this study focused on assessing the role of three different managerial activities (learning orientation, TQM practices, and innovation culture) and their impact on SMEs' financial and non-financial performance.

Financial performance is associated with an organization's capability to yield a return or revenue and is frequently deemed an indicator of business outcomes. In other words, it indicates the effective implementation of an organization's business activities (Orlitzky et al., 2003). Chavan (2009) criticized SMEs for their excessive dependence on measuring financial results and ignoring their non-financial performance since it is the determining factor of value. Due to their excessive dependence on the financial measures of performance, SME managers focused on past events while ignoring the true determinants of success. The delayed nature of financial measures only provides details of past events but not information on future performance. In fact, non-financial performance is a better indicator of an organization's future financial performance. Besides, non-financial performance offers insight into the link between business activities with financial results that considerably impact business performance and competitiveness. For example, the degree of customer satisfaction could indicate future cash flow that would otherwise not be available (Maduekwe \& Kamala, 2016).

\section{LEARNING ORIENTATION}

Learning orientation is one of the crucial entrepreneurship weapons to ensure organizational survival and success (Atitumpong \& Badir, 2018). Furthermore, learning orientation is a mindset in creating knowledge and an essential asset that generates an organization's superior values that cannot be easily 
duplicated by its competitors (Pérez et al., 2019). Learning orientation is also described as an organizational approach to improve an organization's capabilities to continuously develop its activities and performance based on better knowledge, experience, and understanding (M. Baba et al., 2017). It encourages organizations and individuals to build their proficiency and acquire new knowledge, abilities, and competencies. Thus, they would pursue interesting and difficult tasks that enable them to learn from mistakes and concentrate on unfamiliar and new knowledge domains that allow them to learn the most (Attumpong \& Badir, 2018). According to, Sinkula et al. (1997, p. 309), learning orientation is an organization's culture that influences its inclination to structure and implement new knowledge. Additionally, it is a value system that determines a firm's satisfaction based on the adopted approaches by actively assessing the strategies, processes, and practices that influence their organization's performance (Sattayaraksa \& Boon-itt, 2016). This implies that short episodes of organizational training and development are insufficient, considering that learning orientation requires framing a novel organizational culture that modernizes values, conventions, principles, assumptions, and behavior (Y. Baba, 2015; Gil et al., 2018).

In addition, learning orientation enables the top management to use their capacity to question the validity and efficiency of existing competencies, practices, and standards to improve the organization's performance. It also strengthens the organization's learning norms and inspires individuals to acquire fresh insights to increase their capacity to achieve superior performance. Thus, learning orientation reinforces the organization's learning behavior and transforms its climate into a more advanced market and entrepreneurial-oriented, ensuring long-lasting growth and continued existence (Gil et al., 2018; Hussain et al., 2018; Sattayaraksa \& Boon-itt, 2016).

\section{TQM PRACTICES}

TQM is a holistic management approach that enables SMEs to employ quality improvement in their functions to produce and deliver products/services that satisfy customers' needs in a better, faster, safer way and with cheaper manufacturing cost relative to their competitors. This practice is achieved through effective leadership by the organization's top management, which aims to ensure quality across all organizational levels (Al-Dhaafri et al., 2016; Rogo et al., 2017). The adoption of TQM practices allows organizations to restructure their existing rules and regulations to enhance employees' performance regarding the proficiency, effectiveness, and organizational productivity (Iqbal \& Asrar-ul-Haq, 2018).

Moreover, this approach applies quality improvements to provide a competitive edge, customer satisfaction, organizational excellence, innovative solutions, appropriate first-time attitude, and increased output efficiency, productivity, and profitability (Anil \& Satish, 2016; Gharakhani et al., 2013). Hence, TQM practices aim to continuously develop an organization's capacity to effectively respond to customer demand concerning product quality, innovative design, delivery speed, product value, and price. These practices also enable organizations to handle the challenges in the market (Eniola et al., 2019; Madanat \& Khasawneh, 2017). Recently, many SME managers have adopted TQM practices to gain customer loyalty. TQM is a preferred approach to differentiate an SME's activities from its competitors and achieve a better outcome in an increasingly competitive environment (Sule et al., 2017).

In the literature, TQM is defined in different contexts and perspectives with no single generally accepted definition to date (Anil \& Satish, 2016; Bouranta et al., 2019; Haroon \& Shariff, 2016). TQM practices are a sequence of activities involving all individuals in the quality processes that aim for continuous improvement in production operations and techniques and ensure zero defects and customer satisfaction (Kumar et al., 2018). These practices are an integrated organizational-level philosophy to improve product quality, services, and processes to meet customer expectations. Furthermore, it is implemented across all departments to enable all staff to meet or exceed customer requirements and achieve greater organizational value in different markets over its competitors (Al-Ali \& Abu- 
Rumman, 2019). TQM is also viewed as a management philosophy to create radical change, an unconventional philosophy in running organizations, an alternative model, or a comprehensive framework that increases their general performance (Patyal \& Maddulety, 2015).

Most significantly, TQM cannot be implemented by one person; it requires all employees' involvement to implement knowledge and work on quality products, services, and practices (Patyal \& Maddulety, 2015). This inference is based on studies conducted in different countries and sectors. As mentioned before, TQM requires all individuals' continued participation since product and service quality improvement require their involvement in identifying issues and improving manufacturing processes. Specifically, the feasible ideas proposed by employees must be applied. Thus, employees will benefit from TQM implementation since it contributes to their enrichment, development, and training (Iqbal \& Asrar-ul-Haq, 2017).

It should be highlighted that total employee involvement cannot be achieved without a solid strategic orientation towards quality that facilitates efficient TQM implementation. Therefore, the current study proposed that excluding learning orientation prevents implementing efficient TQM practices (Lee \& Lee, 2015). In this context, previous studies have not investigated the role of learning orientation as an effective strategic orientation in employing TQM in SMEs in developing countries. Hence, this study attempted to bridge this significant literature gap.

\section{INNOVATION CULTURE}

Innovation culture is part of an organizational culture that reflects its tendency to compete or resist innovation (Dabić et al., 2018; Sattayaraksa \& Boon-itt, 2016). This fact implies that innovation is central to organizational culture. Dabić et al. (2018) described innovation culture as a group of common values in a firm that produces the best performance by exploring new ideas and opportunities, establishing innovative practices, encouraging innovative behaviors, and constructing infrastructure for innovation processes. Establishing this culture creates the infrastructure and internal environment that inspire employees to support the thoughts, processes, practices, and actions necessary for innovativeness. In other words, innovativeness occurs in a work environment that encourages the sharing of creative and novel outcomes (Villaluz \& Hechanova, 2019). Innovation culture also encourages open communication, reduces competition between individuals, and allows decentralized decisionmaking (Himarsson et al., 2014). It fosters continuous improvements in processes and promotes responsiveness to the market requirements. Besides, organizations can outperform their competitors by achieving desires that even customers are unaware of. This culture enables discovering new ways of performing things, which increases the organizations' competitive edge and innovation performance (Hilmarsson et al., 2014).

Based on the above discussion, this study defined innovation culture as an intangible source that contributes to higher innovation levels by searching and accepting diverse opinions, creating a new way to think and act that supports innovative ideas. This culture accepts mistakes to grow, encourages risk-taking propensity, rewards success, allows flexible management in working hours, solves problems, encourages communication, acknowledges others' work, and encourages team spirit.

\section{CONCEPTUAL FRAMEWORK AND HYPOTHESES}

\section{LEARNING ORIENTATION AND ORGANIZATIONAL PERFORMANCE}

Resource Based View (RBV) demonstrates the link between learning orientation and organizational performance. The concept argues that learning orientation contributes to developing organizational performance by generating continuous knowledge acquisition, new organizational culture, a multifaceted social relationship, and new ideas (Ma et al., 2019; Yabs, 2017). Learning orientation encourages employees' behavioral changes, which is an essential source of competitiveness that produces continuous performance improvement (Mahmoud et al., 2016). Prior studies confirmed that learning 
orientation has superior outcomes, such as better growth, strong competitive advantage, high adaptability, and profitability (Atitumpong \& Badir, 2018; Harvey et al., 2019; Kiyabo \& Isaga, 2019). Additionally, learning orientation involves developing new vision, knowledge, and capabilities critical to a firm's innovation and performance level (Mahmoud et al., 2016).

Naturally, organizational performance with a significant degree of learning orientation is better than a limited level, which is the case in a highly volatile and cutthroat business climate. Nonetheless, numerous scholars submitted that learning orientation and performance is not fully understood to date (Beneke et al., 2016; Shariff et al., 2017; Wahab \& Mahmood, 2015). Hence, there are multiple results and perspectives on the relationship between learning orientation and organizational performance. Many researchers have presented that learning orientation directly influences organizational performance (Kiyabo \& Isaga, 2019; Lestari et al., 2018; Mantok et al., 2019; Nikraftar \& Momeni, 2017; Pérez et al., 2019). On the other hand, several studies demonstrated an indirect relation between learning orientation and organizational performance; thus, it is worth noting that learning orientation influences innovation, which enhances organizational performance (T-S. Lee \& Tsai, 2005; Mahmoud et al., 2016; Rhee et al., 2010).

Meanwhile, several studies have failed to establish that learning orientation directly or indirectly impacts organizational performance (Beneke et al., 2016; Nybakk, 2012; Suliyanto \& Rahab 2012; Wolff et al., 2015). Furthermore, Ebrahimi et al. (2018) investigated the impact of learning orientation on SMEs' performance, revealing that it does not positively influence their performance. In light of these results, this study identified the impact of learning orientation on the organizational performance of SMEs in Kuwait. Thus, the following hypothesis is proposed:

H1: There is a positive effect of learning orientation on organizational performance of SMEs.

\section{TQM PRACTICES AND ORGANIZATIONAL PERFORMANCE}

The RBV theory states that an organization's effective performance can be sustained through its unique and intangible resources, which cannot be easily duplicated, replicated, or substituted (Homaid et al., 2015). TQM practices promote outstanding competitive advantage since they could energize an organization's processes, practices, and rules; thus, hindering potential imitators from gathering the required resources to apply similar techniques successfully. This exceptional combination of culture, individuals, and organizational resources ensures continuous performance development and a sustained competitive advantage (Eniola et al., 2019). Thus, SMEs that want superior long-term performance and adapt successfully to a constantly changing environment should adopt the TQM approach (Benavides-Velasco et al., 2014).

Globally, scholars considered TQM practices a phenomenon connected to a higher level of organizational performance (Al-Dhaafri et al., 2016; Imran et al., 2018; Pambreni et al., 2019; Qasrawi et al., 2017). Singh et al. (2018) investigated the effect of TQM practices (human resource management, organizational leadership, strategic planning and development, customer relationship, and supplier management) on the organizational performance of Indian SMEs and found that TQM practices positively influence performance. This result confirmed that SMEs could achieve better results and superior performance by implementing TQM practices. Furthermore, Eniola et al. (2019) explored the role of TQM in SMEs' performance in Nigeria, revealing that TQM significantly impacts their performance. TQM also allows the firms to achieve continuous improvement in all processes, thus producing desired outcomes. Sahoo and Yadav (2020) contended that several studies had obtained less optimal results regarding the relationship between TQM practices with performance.

Moreover, Sila (2018) indicated a discrepancy in the findings of the impact of TQM practices on performance in various sectors. Due to this inconsistency and the limited studies investigating the effect of TQM practices on the SMEs in the Gulf countries, particularly in Kuwait, it is vital to investigate 
the link between TQM practices and organizational performance in Kuwaiti SMEs. Thus, this study proposed the following hypothesis:

H2: There is a positive effect of TQM practices on organizational performance of SMEs.

\section{LEARNING ORIENTATION, TQM PRACTICES, AND ORGANIZATIONAL PERFORMANCE}

Numerous studies had proven that learning orientation directly impacts SMEs' performance (Kiyabo \& Isaga, 2019; Lestari et al., 2018; Mantok et al., 2019; Nikraftar \& Momeni, 2017; Pérez et al., 2019). On another note, studies also demonstrated that learning orientation directly or indirectly influences organizational performance (Beneke et al., 2016; Ebrahimi et al., 2018; Nybakk, 2012; Suliyanto \& Rahab 2012; Wolff et al., 2015). Hence, several researchers proposed that the role of other intervening variables should be investigated to understand better the learning orientation mechanism that could enhance SMEs' organizational performance (Real et al., 2014; Serna et al., 2016; Vij \& Farooq, 2015).

Therefore, failing to reach the targeted performance through learning orientation results from ineffective managerial practices. To be specific, applying learning orientation as the only internal resource is insufficient to increase SMEs' organizational performance and achieve competitive advantage (Beneke et al., 2016; Ebrahimi et al., 2018). Management approaches such as TQM practices can be integrated with learning orientation to create a conducive organizational environment and culture that promotes a shared vision and commitment to learning. There is also a need to emphasize the importance of sharing knowledge and information in the whole organization and transforming them into sound practices, procedures, and policies to attain organizational goals (Çömez \& Kitapçi, 2016; Lam et al., 2011; C-Y Lee \& Lee, 2015). Learning orientation could transform organizations by focusing on continuous improvement in individual attitudes and creating a conducive culture and values in enhancing individuals' knowledge, skills, and capabilities (Atitumpong \& Badir, 2018; Harvey et al., 2019; Kiyabo \& Isaga, 2019).

Learning orientation also creates an organizational climate that improves employees' abilities, skills, and desires to adopt TQM practices to achieve better performance and sustainability (Mahmood et al., 2015; Mahmud \& Hilmi, 2014). It requires the employees to improve their collective competencies, acquire the ability to learn new working methods, and abandon old habits to develop performance (Mahmood et al., 2015). TQM practices further aim to transform ideas into actual products and services to achieve continuous excellent performance (Sahoo \& Yadav, 2020). Ang et al. (2011) argued that organizations must address learning orientation if they intend to transform from a learning organization into entities that implement TQM practices to develop their organizational performance. Based on this perspective, TQM practices can only be comprehensively implemented with the firm's dedication towards continuous learning (C-Y Lee \& Lee, 2015).

The connection between learning orientation and TQM practices is complementary, whereby both constructs are mutually dependent and have a synergetic effect on one another (C-Y Lee \& Lee, 2015). Thus, both constructs should be implemented concurrently to achieve organizational change and improve its performance. In order to understand the relationship between learning orientation and SMEs performance better, various researchers recommended measuring the effect of learning orientation on organizational performance by integrating intermediate mechanisms to strengthen their relationship (Serna et al., 2016; Vij \& Farooq, 2015). Several studies revealed that TQM practices could influence organizational performance through the role of mediation (Al-Dhaafri \& AlSwidi, 2016; Imran et al., 2018). However, limited studies have investigated the mediating effect of TQM practices in explaining the link between learning orientation and SME's organizational performance in developing countries. Thus, the current study bridges this significant gap by investigating the intermediary role of TQM practices in the relationship between learning orientation and SMEs' performance in Kuwait. Consequently, the following hypothesis is posited: 
The Nexus Between Learning Orientation and Organizational Performance of SMEs

H3: TQM practices mediate the relationship between learning orientation and organizational performance of SMEs.

\section{LEARNING ORIENTATION, INNOVATION CULTURE, AND ORGANIZATIONAL PERFORMANCE}

Learning orientation is a firm's enthusiasm and commitment to increasing its talents, skills, and competencies by acquiring and exchanging new knowledge on market changes, customer requirements, and competitor activities. Besides, it involves keeping up with the latest technological developments of new products and services to ensure that they achieve better and sustained performance than their competitors (Atitumpong \& Badir, 2018). Admittedly, learning orientation is a crucial component in the success and survival of SMEs. Nevertheless, numerous studies have demonstrated the insufficiency of solely investigating the direct impact of learning orientation on SMEs' performance since the findings do not provide a complete picture of the scenario (Beneke et al., 2016; Ebrahimi et al., 2018; Mahmoud et al., 2016; Wolff et al., 2015).

RBV submits that superior organizational performance and competitive advantage depend on other factors not limited to the firm's assets or one of their internal resources (Kiyabo \& Isaga, 2019).

Conversely, it is influenced by task context and follower characteristics (Mokhber et al., 2017) and organizational culture and characteristics (Aboramadan et al., 2019; Buccieri et al., 2019). Hence, innovation culture could be vital in developing organizational performance (Alosani et al., 2020; Dabić et al., 2018). This culture involves the intention to be innovative and how individuals are committed to learning new ways to do business. These impact the orientation towards creating and implementing new ideas (Villaluz \& Hechanova, 2019). This practice also involves the infrastructure that supports employees' innovative work behaviors, configuring the elements of the innovation process, and the management's commitment towards innovation (Hilmarsson et al., 2014). In addition, innovation culture consists of beliefs, systems, encouragement, the ability to protect new technological innovations, and tolerance towards failure. In a nutshell, the core concept of innovation culture is the employees' psychological empowerment to stimulate innovation and enhance performance (Xie et al., 2016). Dabić et al.'s (2018) survey on 253 SMEs in Croatia showed that innovation culture is crucial in ensuring a firm's success and significantly impacts their business performance. Furthermore, Stock et al. (2013) demonstrated that a firm's innovation-oriented culture considerably affects business performance via a product innovation program.

Despite the role of learning orientation as a critical factor of the success and survival of SMEs (Pérez et al., 2019; Sattayaraksa \& Boon-itt, 2016), it is insufficient to merely investigate the direct impact of learning orientation on organizational performance (Ebrahimi et al., 2018; Real et al., 2014; Serna et al., 2016; Vij \& Farooq, 2015). Past studies have examined the different predictors which stimulate the relationship between learning orientation and SMEs' performance. Nonetheless, there is still limited knowledge of the main effect of innovation culture on the relationship between learning orientation and organizational performance. Thus, the absence of sufficient moderator variables could be one reason for the inconclusive results of previous studies investigating the direct effect of learning orientation on organizational performance.

Moreover, few studies have analyzed the intermediary role of innovation culture in the relationship between learning orientation and organizational performance in SMEs in developing countries. Ghasemzadeh et al. (2019) have demonstrated that innovation culture plays a crucial moderating role in linking organizational learning and innovation performance in the pharmaceutical sector. Alosani et al. (2020) revealed that innovation culture has a partial mediating role in the Six Sigma-organizational performance relationship. Additionally, Salge et al. (2012) suggested that innovation activities play a significant moderating role that enhances an organizations' competency in establishing effective strategies that eventually improve organizational performance. 
Therefore, this study examined the moderating effect of innovation culture on the relationship between learning orientation and SMEs' organizational performance since innovation culture helps in promoting innovative strategy, receptiveness to creative ideas, and learning processes; all of which are reflected in achieving outstanding performance (Xie et al., 2016). This study proposed a strong correlation between learning orientation and innovation culture since they could foster creativity among employees and a sharing platform for innovative ideas. Innovation culture is a moderator that eliminates the boundaries between learning orientation and SMEs' business performance and further strengthens their relationship with its ability to generate entrepreneurial spirit and unite employees towards innovative work behavior.

This situation helps increase flexibility and dynamics, and receptiveness towards the unknown. Besides, few studies have measured the moderating role of innovation culture in the relationship between learning orientation and organizational performance of SMEs. Thus, the current study bridged this significant gap by investigating the direct impact of learning orientation that organizations can adopt, depending on their innovation culture. Consequently, the following hypothesis is presented:

H4: Innovation culture moderates the relationship between learning orientation and organizational performance of SMEs.

The conceptual framework of this study is formed based on the results of past studies relevant to the current variables and the RBV theory. RBV states that organizational performance is highly dependent on its existing internal resources and capabilities. This assertion is derived from the fact that organizations can achieve superior performance than their rivals by efficiently utilizing their internal resources. The proposed model illustrates the association between the four variables and their impact on Kuwaiti SMEs. These variables are divided into four categories: (1) independent variable: learning orientation; (2) dependent variable: organizational performance; (3) mediating variable: TQM practices; and (4) moderating variable: innovation culture, as shown in Figure 1. Most significantly, this is one of the few studies that seek to determine the implications of TQM practices in SMEs as a mediating variable and innovation culture as a moderator in the relationship between learning orientation and organizational performance to gain a better insight into it.

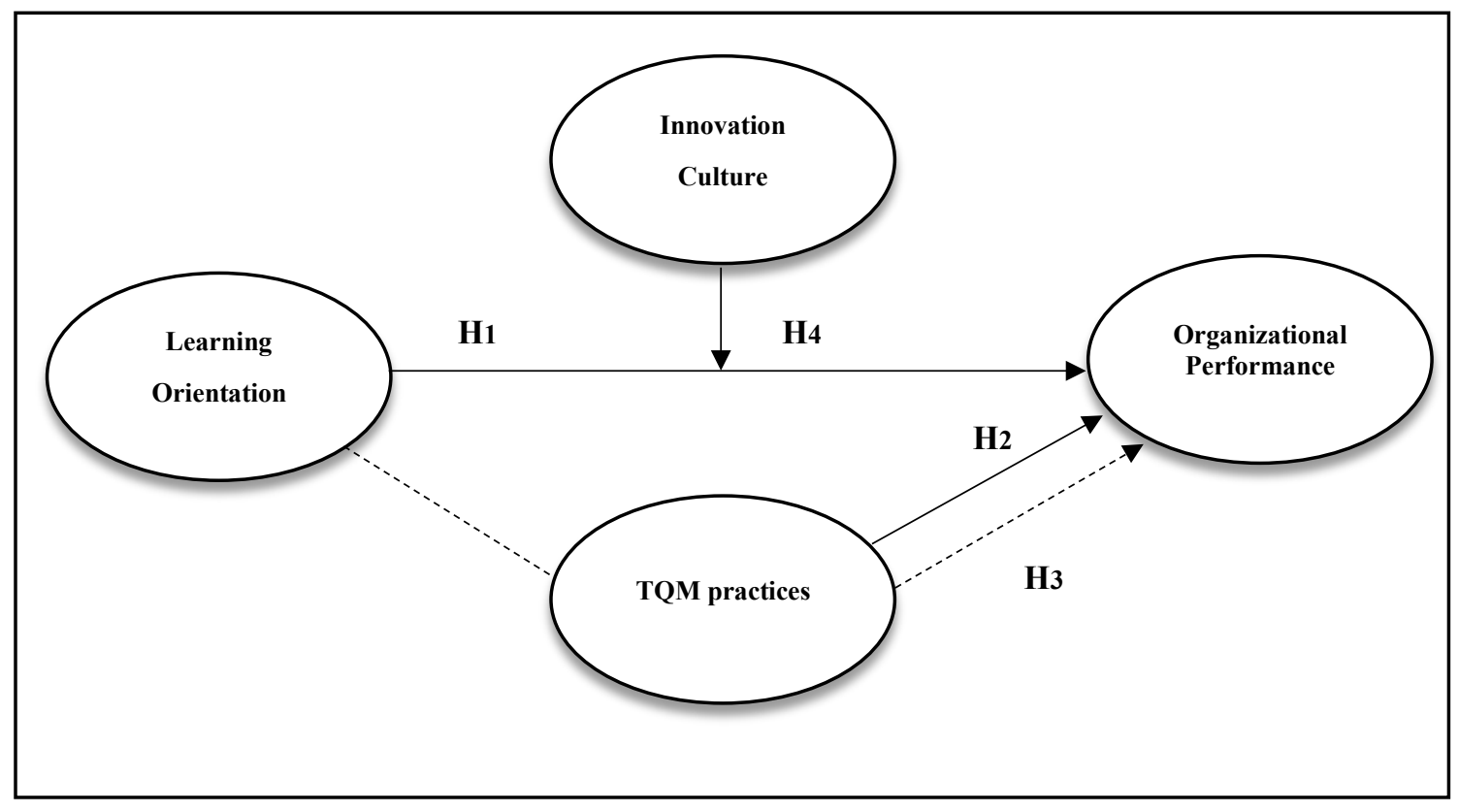

Figure 1. Conceptual Framework 


\section{Methodology}

This study performed an extensive review of conceptual frameworks that were used in previous empirical studies which related with SMEs' organizational performance. Subsequently, the present study proposed a new conceptual model that integrates four crucial constructs (learning orientation, TQM practices, innovation culture, and organizational performance), which aims to address the weakness of SME's organizational performance of in developing countries. This study also employed a quantitative approach, and the structural model was tested using PLS-SEM. In order to verify the conceptual model, the data for Kuwaiti SMEs was gathered by administering a survey questionnaire written in Arabic and English. A five-point Likert scale ranging from "strongly disagree" to "strongly agree" was used. The questionnaire was designed using uncomplicated and straightforward terms to provide comprehensible questions and for the respondents to answer based on their perspectives.

The survey items were adapted from previous studies to ensure content validity, and minor modifications were made when necessary. Furthermore, the measurement scale from Sinkula et al. (1997) was adopted in the context of the present study and used to measure learning orientation. On another note, the measures for TQM practices were adopted from Sahoo and Yadav (2017), while the scales for innovation culture were based on Cormican and O'Sullivan (2004). The items for measuring organizational performance were adopted from Fang et al. (2014) and Flynn et al. (2010).

The SMEs were selected with the assistance of the government agencies involved in promoting the socio-economic development and growth of entrepreneurs in Kuwait (Ministry of Commerce and Industry and Kuwait National Fund for SME Development). The targeted population was the owners and CEOs of SMEs registered in the Ministry of Commerce and Industry in Kuwait, and they were selected using a random sampling method. The researchers distributed a total of 500 questionnaires using both online survey and paper-based questionnaires through a face-to-face survey. 392 questionnaires were returned, with 384 useable questionnaires after data cleaning. The data were initially analyzed using the Statistical Package for the Social Sciences (SPSS) to address the problems concerning missing values, outliers, and non-normality. Smart Partial Least Squares (PLS) 3 was then used to carry out the primary analysis. Finally, assessment of the measurement model considered the values for reliability and validity while the hypotheses were tested using a bootstrapping method to determine the significance of the proposed relationships.

\section{RESULTS}

Data analysis was conducted using the PLS-SEM technique with the Smart PLS version 3.3.2. Subsequently, a two-stage approach was employed to test the hypotheses of the study. In the first stage, the measurement model was used, which comprised convergent and discriminant validity. Once the validities were confirmed, the hypothesis testing of the structural model was performed. Convergent validity indicates when a particular item measures a latent variable that it is supposed to measure (Hair et al., 2017). The parameters assessed in the convergent validity test are loading, average variance extracted (AVE), and composite reliability (CR). The value of loadings should be $\geq 0.5$, the AVE should be $\geq 0.5$, while the CR should be $\geq 0.7$. Table 1 shows that all values for loadings, AVEs, and CRs are higher than the threshold values recommended by Hair et al. (2017), thus confirming that the convergent validity in the current study has been established. 
Table 1. Convergent Validity

\begin{tabular}{|c|c|c|c|c|}
\hline Construct & Item & Loading & CR & AVE \\
\hline \multirow[t]{5}{*}{ Learning Orientation (LO) } & LO1 & 0.924 & \multirow[t]{5}{*}{0.958} & \multirow[t]{5}{*}{0.821} \\
\hline & $\mathrm{LO} 2$ & 0.950 & & \\
\hline & $\mathrm{LO} 3$ & 0.898 & & \\
\hline & $\mathrm{LO} 4$ & 0.802 & & \\
\hline & LO5 & 0.947 & & \\
\hline \multirow[t]{5}{*}{ TQM practices } & TQM1 & 0.911 & \multirow[t]{5}{*}{0.963} & \multirow[t]{5}{*}{0.837} \\
\hline & TQM2 & 0.925 & & \\
\hline & TQM3 & 0.911 & & \\
\hline & TQM4 & 0.925 & & \\
\hline & TQM5 & 0.904 & & \\
\hline \multirow{5}{*}{$\begin{array}{l}\text { Organizational Perfor- } \\
\text { mance (OP) }\end{array}$} & OP1 & 0.906 & \multirow[t]{5}{*}{0.969} & \multirow[t]{5}{*}{0.864} \\
\hline & OP2 & 0.951 & & \\
\hline & OP3 & 0.936 & & \\
\hline & OP4 & 0.911 & & \\
\hline & OP5 & 0.942 & & \\
\hline \multirow[t]{5}{*}{ Innovation Culture (IC) } & IC1 & 0.926 & \multirow[t]{5}{*}{0.977} & \multirow[t]{5}{*}{0.896} \\
\hline & IC2 & 0.949 & & \\
\hline & IC3 & 0.951 & & \\
\hline & IC4 & 0.941 & & \\
\hline & IC5 & 0.965 & & \\
\hline
\end{tabular}

Figure 2 presents the measurement model of the study where learning orientation is the independent variable, organizational performance is the dependent variable, TQM practice is the mediating variable and innovation culture is the moderator. All variables contain five items each. The above measurement model confirms that the values of the factor loading for all the items are above 0.7 which means that all the items are perfectly loaded on their respective construct. 


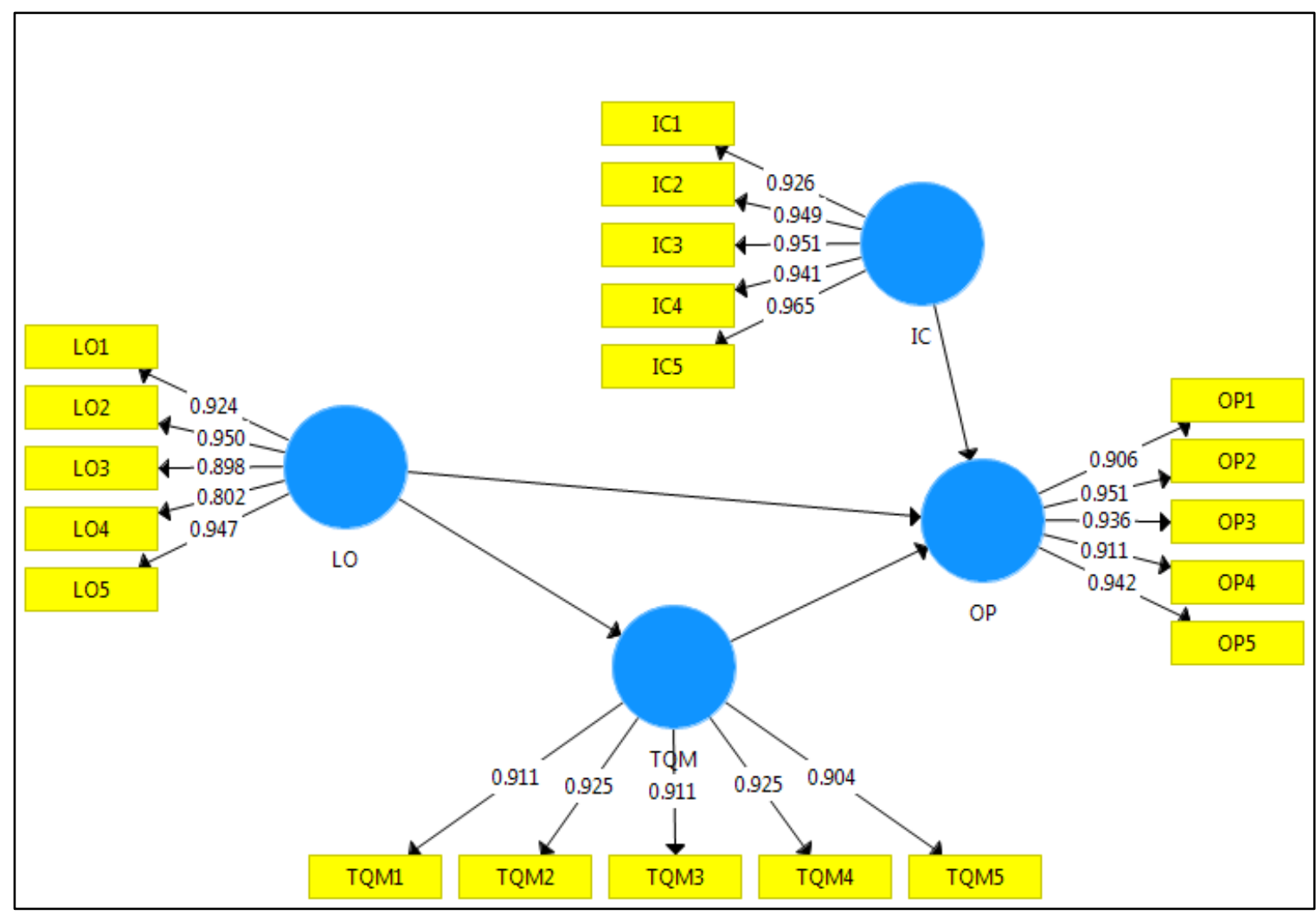

Figure 2. Measurement Model

The discriminant validity presented in Table 2 follows Fornell and Larcker's (1981) suggestion, whereby the square root of AVE for each construct must be greater than the correlation coefficient of the constructs presented in the model. Hence, this condition has been satisfied.

Table 2. Discriminant Validity

\begin{tabular}{|l|l|l|l|l|}
\hline & IC & LO & OP & TQM \\
\hline IC & 0.947 & & & \\
\hline LO & 0.139 & 0.906 & & \\
\hline OP & 0.910 & 0.139 & 0.930 & \\
\hline TQM practices & 0.221 & 0.169 & 0.216 & 0.915 \\
\hline
\end{tabular}

\section{STRUCTURAL MODEL}

Bootstrapping was performed to obtain the t-values, and the results of the hypotheses examining the direct and indirect relationships are presented in Table 3. The results showed that learning orientation has a considerable effect on organizational performance with $\mathrm{p}<0.035$, and TQM practices significantly affect organizational performance with $\mathrm{p}<0.000$. The result also indicated that TQM practices mediate the effect of learning orientation on organizational performance with $\mathrm{p}<0.011$. 
Table 3. Direct and mediated relationships

\begin{tabular}{|l|l|l|l|l|}
\hline Relationship & Beat & SE & T Statistics & P Values \\
\hline H1: LO -> OP & 0.107 & 0.051 & 2.116 & 0.035 \\
\hline H2: TQM practices -> OP & 0.201 & 0.050 & 4.044 & 0.000 \\
\hline H3: LO -> TQM practices -> OP & 0.034 & 0.013 & 2.567 & 0.011 \\
\hline
\end{tabular}

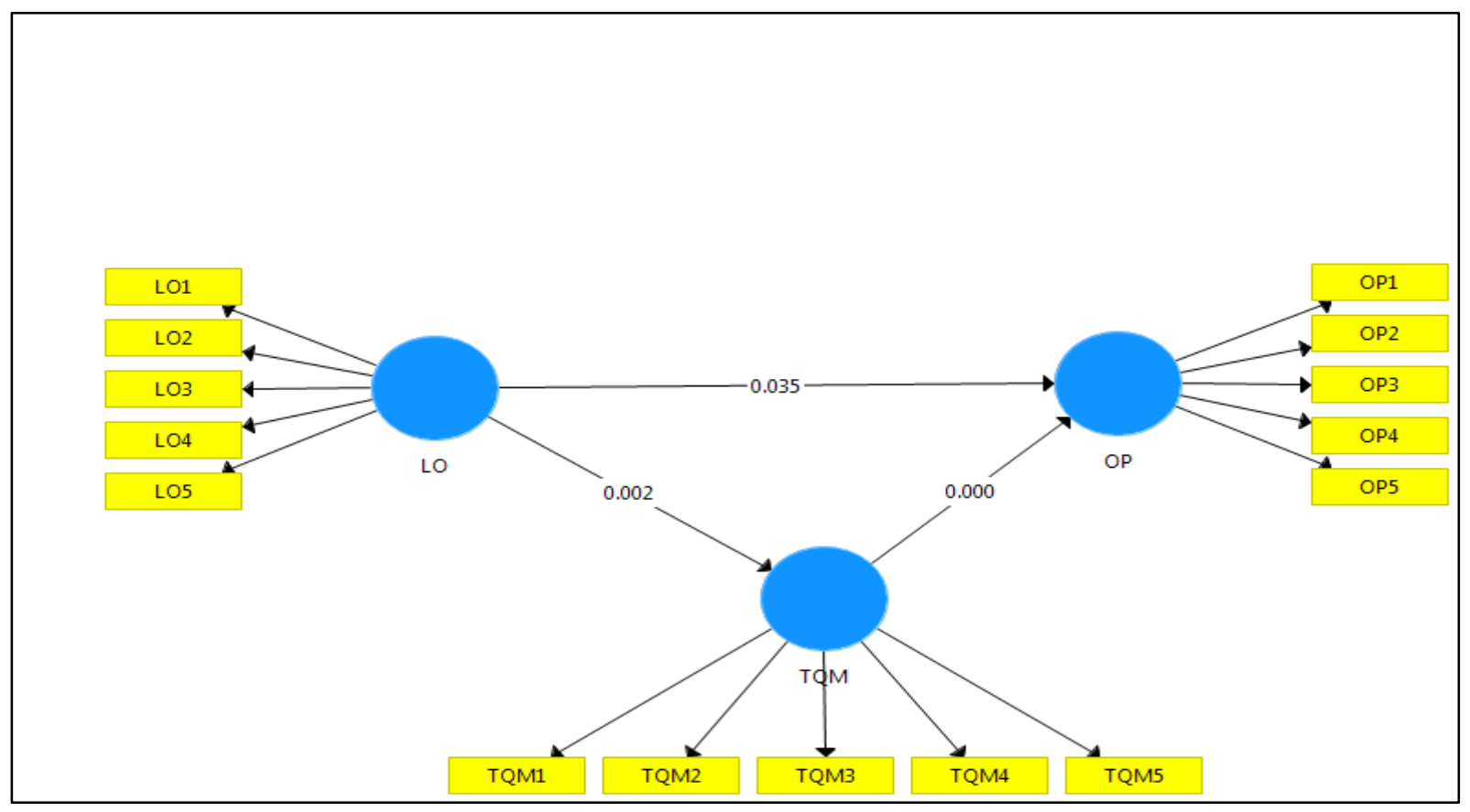

Figure 3. Structural Model

Figure 3 illustrates the structural model of the current study. The model shows the direct relationship between learning orientation and organizational performance. It also depicts the indirect relationship of learning orientation with organizational performance through the mediation of TQM practices.

\section{RESULT FOR MODERATION}

This study also used the bootstrapping technique to test the moderating effect. H4 suggested that innovation culture moderates the link between learning orientation and organizational performance in Kuwaiti SMEs. The results in Table 4 show that the moderation effect is significant with $\mathrm{p}<0.027$, and hence the hypothesis is supported.

Table 4. Result for Moderation

\begin{tabular}{|l|l|l|l|l|}
\hline Relationship & Beat & SE & T value & P Values \\
\hline H4:LO $\rightarrow$ OP (Moderator IC) & 0.040 & 0.018 & 2.221 & 0.027 \\
\hline
\end{tabular}




\section{Discussion OF THE FINDINGS}

The empirical findings of this study showed that organizational performance is positively affected by learning orientation at the 0.05 level of significance $(\beta=0.107, t=2.116, p<0.035)$. Therefore, $(\mathrm{H} 1)$ is supported. This result is consistent with those obtained by earlier studies (Kiyabo \& Isaga, 2019; Lestari et al., 2018; Mantok et al, 2019; Nikraftar \& Momeni, 2017; Pérez et al., 2019) which have proven that learning orientation is fundamental for the continuous development of SMEs performance in the background of a multifaceted environment. Kiyabo and Isaga (2019) made an inference based on the data gathered from 300 owners and managers of SMEs that learning orientation is one of efficacious strategic orientations that have a significant influence to create competitive advantage that promotes SMEs' performance. Similarly, Pérez et al. (2019) have shown the strong impact of learning orientation on the business performance of micro and SMEs business performance and suggested that the top management of these firms should commit to learning processes in order to be able to create superior competencies and to be more competitive; however, they have to first review their current method of learning.

$\mathrm{H} 2$ tested the TQM practices-organizational performance relationship, which is supported by the empirical outcomes at a 0.05 level of significance $(\beta=0.201, \mathrm{t}=4.044, \mathrm{p}<0.000)$. Thus, H2 is confirmed. This finding is consistent with the studies that suggested TQM practices as a holistic managerial approach that beneficially impacts SMEs' performance (Al-Dhaafri et al., 2016; Imran et al., 2018; Pambreni et al., 2019; Qasrawi et al., 2017). To elaborate, G. Ali et al. (2020) conducted a study on 393 owners and managers to analyze the joint influence of entrepreneurial orientation, market orientation, TQM practices, and SMEs' organizational performance in Saudi Arabia. It was discovered that the impact of TQM practices is greater than the effect of entrepreneurial orientation and market orientation in enhancing organizational performance and development of Saudi Arabian SMEs.

Similarly, Hilman et al. (2019) revealed that TQM practices significantly influence SMEs' performance in Riyadh, Mecca, and Eastern Saudi Arabia regions. The researchers also demonstrated that TQM practices could ensure a constant quality improvement in processes and employees' efforts to achieve the expected results. Thus, TQM is a critical component that ensures the success of any business operating in a constantly changing environment. This approach enables SMEs to cope with changes in customer needs, production volume, and innovation. As mentioned above, most studies have proven the strong impact of learning orientation on SMEs' performance (Kiyabo \& Isaga, 2019; Lestari et al., 2018; Mantok et al., 2019; Nikraftar \& Momeni, 2017; Pérez et al., 2019).

Despite this fact, other researchers urged for more research to gain better insights into the association of learning orientation with performance, especially in developing countries, by introducing strong mediation mechanisms that enhance the relationship between learning orientation and performance (Real et al., 2014; Serna et al., 2016; Vij \& Farooq, 2015). In this context, the current study combined the role of TQM practices with the link between learning orientation and organizational performance to understand the mechanism behind the role of learning orientation in strengthening SMEs' organizational performance. The findings in this present study showed that TQM practices play a vital mediating role in the link between learning orientation and SMEs' organizational performance at a 0.05 level of significance $(\beta=0.034, \mathrm{t}=2.567, \mathrm{p}<0.011)$. Therefore, $\mathrm{H} 3$ is accepted.

This result is consistent with C-Y Lee and Lee (2015), who showed that TQM practices significantly and positively impact business performance, thus enhancing its intermediary role in the relationship between organizational learning with business performance. Finally, to strengthen the association of learning orientation with SMEs' performance and deal with the differences in the direct influence of learning orientation on organizational performance, this study examined the moderating role of innovation culture between learning orientation and organizational performance. This study revealed that the outcome of H4 is significant at a 0.05 level of significance $(\beta=0.040, t=2.221, p<0.027)$, and thus, $\mathrm{H} 4$ is supported. This result further confirmed previous studies that have demonstrated the 
decisive role of innovation culture as an intervening variable that develops organizational performance (Alosani et al., 2020; Ghasemzadeh et al., 2019) and an internal environment that improves employee work behavior to learn and innovate continuously.

\section{CONCLUSION}

Kuwait is a developing country and has recently increased the role of SMEs due to its importance in diversifying the sources of national income, providing job opportunities, and embracing innovative practices. Therefore, this study contributed to the current literature on SMEs by identifying the significant factors, namely learning orientation, TQM practices and innovation culture, and their impact on SMEs' organizational performance. As a relatively new concept, learning orientation has not been fully understood in developing countries such as Kuwait. Contrasting scholars' opinions and research findings regarding the direct impact of learning orientation on SMEs' performance has made it necessary to examine and bridge the gap between the mutual influence of learning orientation and other variables, such as TQM practices and innovation culture.

The results indicated that the SMEs in Kuwait considered learning orientation a significant component of their businesses with a pronounced effect on their performance. The results also proposed that learning orientation, TQM practices, and innovation culture improved organizational performance. These three major abilities caused SMEs to acquire and utilize new knowledge and adapt continuously to environmental change. Hence, learning orientation and TQM practices should stimulate an organization's processes to develop SMEs' performance in Kuwait. This practice could be performed by creating an organizational culture where innovation and openness to new ideas become an integral part of business strategy. In conclusion, SMEs that focus on continuous learning and systemically managing their activities could attain better performance over firms that disregard such approaches. Therefore, the conceptual model has made significant theoretical and practical contributions to the existing knowledge on SMEs' performance.

\section{Theoretical Contributions}

The research model proposed in this study has provided greater insight into the association of learning orientation, TQM practices, and innovation culture with SMEs' organizational performance. This study discussed the mediating role of TQM practices and the moderating role of innovation culture in the relationship between learning orientation and organizational performance, as presented in Figure 1. In terms of theoretical implications, this study had extended the body of knowledge by highlighting the positive and direct role of learning orientation on SMEs' performance and responding to the demand to examine this relationship. This need is due to the beneficial impact of learning orientation on organizational performance in developing countries, which remains unclear and should be studied extensively (Beneke et al., 2016; Harvey et al., 2019; Kiyabo \& Isaga, 2019; Wolff et al., 2015).

Secondly, this study contributed to the existing literature and is a pioneer study that investigates the mediating role of TQM practices on the relationship between learning orientation and organizational performance in SMEs, which have not been given the deserved academic attention. Therefore, this study increased the understanding of the association between learning orientation and organizational performance and how learning orientation brings firms toward success. Besides, this study contributed to the RBV theory by highlighting learning orientation as a vital internal source that harnesses all the internal competencies to achieve excellent outcomes. Thirdly, the current study contributed by examining the role of innovation culture as a moderator variable on the nexus between learning orientation and organizational performance and emphasized the role of learning orientation in creating the internal environment that stimulates innovativeness, resulting in performance improvement and effectiveness. 


\section{Practical Contributions}

The outcomes of this study offer new insights to the owners/managers of SMEs about the significant of learning orientation in helping firms acquire knowledge and share this knowledge amongst employees in order to successfully implement them; it would also help the owners/managers of SMEs to create an environment that aims to continuously evaluate their operations and activities and thus makes it possible for them to abandon the adoption of current and old methods. The findings of the current study confirmed that learning orientation and TQM practices have a complementary relationship.

Together, they produce better SMEs performance by emphasizing the commitment to learning and developing continuous improvement in processes, capabilities, and performance, and thus this association should be encouraged. This practice is possible by creating an organizational culture where innovation and receptiveness to new ideas are an integral part of firm orientations and strategies. Innovation culture can help firms maximize the benefits of learning orientation in product and process innovation. Therefore, SMEs that focus on learning orientation and innovation culture are expected to perform better than those that do not.

\section{Limitations AND Future RESEARCH}

The present study constructed a specific model for Kuwaiti SMEs. In order to generalize the findings of this study, future research must study this particular framework against the backdrop of other countries and industries. In this specific study, the model considered only TQM practices and innovation culture as the intervening variables to understand their effective role in the association of learning orientation with SMEs performance.

Nonetheless, there are other mechanisms, for instance, market orientation, technological orientation, and entrepreneurial orientation, that could function together with learning orientation to influence organizational performance. Future researchers should include these variables in their investigations to better understand the effective predictors that can efficiently develop organizational performance. Ultimately, a longitudinal study could produce a better conclusion.

\section{REFERENCES}

Abdollahi, H., Razm, K., \& Tan, H. (2014). TQM and market orientation's impact on SMEs' performance. Management Science Letters, 4(5), 887-892. https://doi.org/10.5267/j.msl.2014.4.001

Aboramadan, M., Albashiti, B., Alharazin, H. \& Zaidoune, S. (2019). Organizational culture, innovation and performance: A study from a non-western context. Journal of Management Development, 39(4). https://doi.org/10.1108/JMD-06-2019-0253.

Abu-Aisheh, A. (2018). Entrepreneurship and economic growth: Case of Kuwait. Kuwait University, College of Business Administration. Spring 2018. https://www.sciencespo.fr/kuwait-program/wpcontent/uploads/2018/11/Alia-Ali-Abu-Aisheh-Entrepreneurship-and-Economic-Growth.pdf

Abukumail, A., Karam, N., \& Al-Otaibi, G. (2016). Building Kuwait's future, one small enterprise at a time. MENA Knowledge and Learning Quick Notes Series; No. 153. World Bank.

Afriyie, S., Du, J., \& Musah, A. (2019). Innovation and marketing performance of SME in an emerging economy: The moderating effect of transformational leadership. Journal of Global Entrepreneurship Research, 9(40), 1-25. https://doi.org/10.1186/s40497-019-0165-3

AL-Ali, A., \& Abu-Rumman, A. (2019). The role of total quality management in the face of challenges: A study in lafarge-Jordan. Academy of Strategic Management Journal, 18(1), 1-16.

Al-Dhaafri, H., Al-Swidi. A., \& Yusoff, R. (2016). The mediating role of TQM and organizational excellence, and the moderating effect of entrepreneurial organizational culture on the relationship between ERP and 
organizational performance. The TQM Journal, 28(6), 991-1011. https://doi.org/10. 1108/TQM-04-20140040.

Al-duwailah, F., Mansouri, H., \& Ben Ayad, M. (2019). The impact of entrepreneurship drivers on Kuwaiti entrepreneurs' capabilities and opportunities. Revue Des Sciences Commerciales, 18(1), 35-49.

Alhabashi, K. (2015). Financing for small and medium enterprises: The role of islamic financial institutions in Kunvait $[\mathrm{PhD}$ thesis. University of Gloucestershire].

Ali, G., Hilman, H., \& Gorondutse, A.H. (2020). Effect of entrepreneurial orientation, market orientation and total quality management on performance: Evidence from Saudi SMEs. Benchmarking: An International Journal, 27(4), 1503-1531. https://doi.org/10.1108/BIJ-08-2019-0391

Ali, Y., Younus, A., Khan, A., \& Pervez, H. (2020). Impact of lean, Six Sigma and environmental sustainability on the performance of SMEs. International Journal of Productivity and Performance Management, [ahead-of-print]. https://doi.org/10.1108/IJPPM-11-2019-0528

Ali, Z., Gongbing, B., \& Mehreen, A. (2019). Supply chain network and information sharing effects of SMEs' credit quality on firm performance: Do strong tie and bridge tie matter?. Journal of Enterprise Information Management, 32(5), 714-734. https://doi.org/10.1108/JEIM-07-2018-0169

Alosani, M., Yusoff, R., Al-Ansi, A., \& Al-Dhaafri, H. (2020). The mediating role of innovation culture on the relationship between Six Sigma and organisational performance in Dubai police force. International Journal of Lean Six Sigma, [ahead-of-print]. https://doi.org/10.1108/IJLSS-11-2019-0110

AlQershi, N., Mokhtar, S., \& Abas, Z. (2020). CRM dimensions and performance of SMEs in Yemen: The moderating role of human capital. Journal of Intellectual Capital [ahead-of-print]. https://doi.org/10.1108/JIC-05-2020-0175

Alzougool, B. (2019). The innovativeness of small and medium enterprises in Kuwait. Journal of Advanced Management Science, 7(4), 142-147. https://doi.org/10.18178/joams.7.4.142-147

Ang, Y., Tan, V,. \& Chong, A. (2011). The impact of TQM practices on learning organization and customer orientation: A survey of small service organizations in Malaysia. International Journal of Services, Economics and Management, 3(1), 62-77. https://doi.org/10.1504/ijsem.2011.037178

Anil, A., \& Satish K. (2016). Investigating the relationship between TQM practices and firm's performance: A conceptual framework for Indian organizations. Procedia Technology, 24, 554-561. https://doi.org/10.1016/i.protcy.2016.05.103

Asemokha, A., Musona, J., Torkkeli, L. \& Saarenketo, S. (2019). Business model innovation and entrepreneurial orientation relationships in SMEs: Implications for international performance. Journal of International Entrepreneurship, 17(3), 425-453. https://doi.org/10.1007/s10843-019-00254-3

Atitumpong, A., \& Badir, Y. (2018). Leader-member exchange, learning orientation and innovative work behavior. Journal of Workplace Learning, 30(1), 32-47. https://doi.org/10.1108/JWL-01-2017-0005.

Baba, M., Mahmood, R., \& Halipah, A. (2017). The moderating role of environmental turbulence on the relationship between organizational learning and firm innovativeness. International Journal of Management Research \& Review, 7(2), 148-159.

Baba, Y. (2015). Does learning orientation matter for nonprofit organization performance? Empirical evidence from Ghana. Leadership \& Organization Development Journal, 36(3), 234-252. https://doi.org/10.1108/lodj05-2013-0056

Bahta, D., Yun, J., Islam, M. R., \& Ashfaq, M. (2020). Corporate social responsibility, innovation capability and firm performance: Evidence from SME. Social Responsibility Journal, [ahead-of-print]. https://doi.org/10.1108/srj-12-2019-0401

Bannour, S., \& Mtar, K. (2019). To what extent do quality procedures determine the performance of French SMEs?. Research Policy, 25(5), 785-804. https://doi.org/10.1108/ijqrm-01-2018-0002

Benavides-Velasco, C., Quintana-García, C., \& Marchante-Lara, M. (2014). Total quality management, corporate social responsibility and performance in the hotel industry. International Journal of Hospitality Management, 41, 77-87. https://doi.org/10.1016/j.ijhm.2014.05.003 
The Nexus Between Learning Orientation and Organizational Performance of SMEs

Beneke, J., Blampied, S., Dewar, N., \& Soriano, L. (2016). The impact of market orientation and learning orientation on organisational performance: A study of small to medium-sized enterprises in Cape Town, South Africa. Journal of Research in Marketing and Entrepreneurship, 18(1), 90-108. https://doi.org/10.1108/jrme-06-2015-0033

Bouranta, N., Psomas, E., Suárez-Barraza, M., \& Jaca, C. (2019). The key factors of total quality management in the service sector: A cross-cultural study. Benchmarking An International Journal, 26(3), 893-921. https://doi.org/10.1108/BIJ-09-2017-0240.

Buccieri, D., Javalgi, R., \& Cavusgil, E. (2019). International new venture performance: Role of international entrepreneurial culture, ambidextrous innovation, and dynamic marketing capabilities. International Business Review, 29(2), 1-15. https://doi.org/10.1016/j.ibusrev.2019.101639

Carter, W., Nesbit, P., Badham, R., Parker, S., \& Sung, L. (2018). The effects of employee engagement and selfefficacy on job performance: A longitudinal field study. International Journal of Human Resource Management, 29(17), 2483-2502. https://doi.org/10.1080/09585192.2016.1244096

Chavan, M. (2009). The balanced scorecard: A new challenge. Journal of Management Development, 28(5), 393-406.

Çömez, P., \& Kitapçi, H. (2019). The effect of quality orientation, market orientation and learning orientation on firm innovativeness. European Journal of Business and Social Sciences, 4(12), 182-202.

Cormican, K., \& O'Sullivan, D. (2004). Auditing best practice for effective product innovation management. Technovation, 24(10), 819-829. https://doi.org/10.1016/s0166-4972(03)00013-0

Dabić, M., Lažnjak, J., Smallbone, D., \& Švarc, J. (2018). Intellectual capital, organisational climate, innovation culture, and SME performance: Evidence from Croatia. Journal of Small Business and Enterprise Development, 26(4), 522-544. https://doi.org/10.1108/JSBED-04-2018-0117

Dana, L., Palalić, R., \& Ramadaini, V.(2021). Entrepreneurship in the Gulf cooperation council region: Evolution and future perspectives. World Scientific. https://ideas.repec.org/b/wsi/wsbook/q0239.html

Ebrahimi, P., Shafiee, B., Gholampour, A., \& Yousefi, L. (2018). Impact of organizational innovation, learning orientation and entrepreneurship on SME performance: The moderating role of market turbulence and ICT. In D. Khajeheian, M. Friedrichsen, \& W. Mödinger (Eds), Competitiveness in emerging markets (pp. 447480). Springer. https://doi.org/10.1007/978-3-319-71722-7_23

Eniola, A., Olorunleke, G., Akintimehin, O., Ojeka, J., \& Oyetunji, B. (2019). The impact of organizational culture on total quality management in SMEs in Nigeria. Heliyon, 5(8), 1-10. https://doi.org/10.1016/j.heliyon.2019.e02293

Falahat, M., Ramayah, T., Soto-Acosta, P., \& Lee, Y. (2020). SMEs internationalization: The role of product innovation, market intelligence, pricing and marketing communication capabilities as drivers of SMEs' international performance. Technological Forecasting and Social Change, 152, [ahead-of-print]. https://doi.org/10.1016/i.techfore.2020.119908

Fang, S., Chang, E., Ou, C., \& Chou, C. (2014). Internal market orientation, market capabilities and learning orientation. European Journal of Marketing, 48(1/2), 170-192. https://doi.org/10.1108/EJM-06-2010-035.

Ferraris, A., Mazzoleni, A., Devalle, A., \& Couturier, J. (2019). Big data analytics capabilities and knowledge management: Impact on firm performance. Management Decision, 57(8), 1923-1936. https://doi.org/10.1108/md-07-2018-0825

Flynn, B., Huo, B., \& Zhao, X. (2010). The impact of supply chain integration on performance: A contingency and configuration approach. Journal of Operations Management, 28(1), 58-71. https://doi.org/10.1016/i.jom.2009.06.001

Fornell, C., \& Larcker, D. (1981). Evaluating structural equation models with unobservable variables and measurement error. Journal of Marketing Research, 18(1), 39-50. https://doi.org/10.1177/002224378101800104

Gharakhani, D., Hossein, R., Mohammad, R., \& Farahmandian, A. (2013). Total quality management and organizational performance. American Journal of Industrial Engineering, 1(3), 46-50. 
Ghasemzadeh, P., Nazari, J. A., Mandana, F., \& Gholamhossein, M. (2019). Moderating role of innovation culture in the relationship between organizational learning and innovation performance. The Learning Organization, 26(3), 289-303. https://doi.org/10.1108/TLO-08-2018-0139

Gil, A., Moya, B., \& Bellido, J. (2018). The effect of leadership in the development of innovation capacity: A learning organization perspective. Leadership \& Organization Development Journal, 39(6), 694-711. https://doi.org/10.1108/lodj-12-2017-0399

Hafeez, H., Shariff, M., \& Lazim, H. (2013). Does innovation and relational learning influence SME performance? An empirical evidence from Pakistan. Asian Social Science, 9(15), 204-213. https://doi.org/10.5539/ass.v9n15p204

Hair, J., Hollingsworth, C. L., Randolph, A. B., \& Chong, A. Y. L. (2017). An updated and expanded assessment of PLS-SEM in information systems research. Industrial Management and Data Systems, 117(3), 442-458. https://doi.org/10.1108/IMDS-04-2016-0130

Haroon, U., \& Shariff, M. N. M. (2016). The interplay of innovation, TQM practices and SMEs performance in Pakistan: Moderating effects of knowledge inertia and external environment. Economics and Law, 9(2), 5762.

Harvey, J., Johnson, K., Roloff, K., \& Edmondson, A. (2019). From orientation to behaviour: The interplay between learning orientation, open-mindedness, and psychological safety in team learning. Human Relations, 72(11), 1-26. https://doi.org/10.1177\%2F0018726718817812

Hilman, H., Ali, G,. \& Gorondutse, A. (2019). The relationship between TQM and SMEs' performance: The mediating role of organizational culture. International Journal of Productivity and Performance Management, 69(1), 61-84. https://doi.org/10.1108/ijppm-02-2019-0059

Hilmarsson, E., Oskarsson, G., \& Gudlaugsson, T. (2014). The relationship between innovation culture and innovation performance. International Journal of Business Research, 14(1), 86-95.

https://doi.org/10.18374/ijbr-14-1.8

Homaid, A., Minai, M., \& Rahman, H. (2015). TQM and performance linkage in the microfinance institutions: The mediating role of IT capability. Asian Social Science, 11(21), 213-230. https://doi.org/10.5539/ass.v11n21p213

Hoque, A., \& Awang, Z. (2019). Does gender difference play moderating role in the relationship between entrepreneurial marketing and Bangladeshi SME performance? Accounting, 5(1) 35-52.

https://doi.org/10.5267/j.ac.2018.6.001

Huang, J., \& Li, Y. (2017). The mediating role of ambidextrous capability in learning orientation and new product performance. Journal of Business and Industrial Marketing, 32(5), 613-624. https://doi.org/10.1108/ibim-01-2015-0017

Hussain, J., Shah, F., Rahman, W., Khan, Y. (2018). learning orientation and performance: the interaction effect of entrepreneurial orientation. Pakistan business review, 19(4), 960-977.

Hussain, J., Shah, F., Rahman, W., Y Khan, Y. (2018). Learning orientation and performance: The interaction effect of entrepreneurial orientation. Pakistan Business Review, 19(4), 960-977.

Imran, M., Norasyikin, S., \& Aziz, A. (2018). The influence of TQM on export performance of SMEs: Empirical evidence from manufacturing sector in Pakistan using PLS-SEM. Management Science Letters, 8(5), 483-496. https://doi.org/10.5267/j.msl.2018.3.003

Iqbal, A., \& Asrar-ul-Haq, M. (2017). An empirical investigation on TQM practices and knowledge sharing mediation in software industry. The TQM Journal, 29(5), 725-743. https://doi.org/10.1108/tqm-03-2017$\underline{0038}$

Iqbal, A., \& Asrar-ul-Haq, M. (2018). Establishing relationship between TQM practices and employee performance: The mediating role of change readiness. International Journal of Production Economics, 203(C) 62-68. https://doi.org/10.1016/j.ijpe.2018.05.034

Kafetzopoulos, D. (2020). Performance management of SMEs: A systematic literature review for antecedents and moderators. International Journal of Productivity and Performance Management, [ahead-of-print]. https://doi.org/10.1108/ijppm-07-2020-0349 
The Nexus Between Learning Orientation and Organizational Performance of SMEs

Kamau, M., \& Wanyoike, W. (2019) Corporate culture and organizational performance: A case of Mayfair casino, Nairobi city county, Kenya. Global Journal of Commerce and Management Perspective, 8, 1. https://www.longdom.org/articles/corporate-culture-and-organizational-performance-a-case-of-mayfaircasino-nairobi-city-county-kenya.pdf

Kiyabo, K., Isaga, N. (2019). Strategic entrepreneurship, competitive advantage, and SMEs' performance in the welding industry in Tanzania. Journal of Global Entrepreneurship Research, 9(62), 1-23. https://doi.org/10.1186/s40497-019-0188-9

Kumar, V., Sharma, R., \& Verma, P. (2018). Mapping the TQM implementation: An empirical investigation of the cultural dimensions with different strategic orientation in Indian firms. Benchmarking: An International Journal, 25(8), 3081-3116. https://doi.org/10.1108/bij-06-2017-0150

Lam, S., Lee, V., Ooi, K., \& Lin, B. (2011). The relationship between TQM, learning orientation and market performance in service organisations: An empirical analysis. Total Quality Management, 22(12), 1277-1297. https://doi.org/10.1080/14783363.2011.631337

Lee, C-Y., \& Lee, H. (2015). The integrated relationship among organizational learning, TQM and firm's business performance: A structural equation modeling approach. International Business Research, 8(5), 43-54. https://doi.org/10.5539/ibr.v8n5p43

Lee, T-S., \& Tsai, H. (2005). The effects of business operation mode on market orientation, learning orientation and innovativeness. Industrial Management \& Data Systems, 105(3), 325-348. https://doi.org/10.1108/02635570510590147

Lestari, E., Ardianti, F., \& Rachmawati, L. (2018). Firm performance model in small and medium enterprises (SMEs) based on learning orientation and innovation. International Conference on Green Agro-industry and Bioeconomy, 131(2018), Batu City, East Java, Indonesia. 1-7.

Lo, M., Wang, Y., Wah, C., \& Ramayah, T. (2016). The critical success factors for organizational performance of SMEs in Malaysia: A partial least squares approach. Review of Business Management, 18(61), 370-391. https://doi.org/10.7819/rbgn.v18i61.3058

Ma, H., Sun, Q., Gao, Y., \& Gao, Y. (2019). Resource integration, reconfiguration, and sustainable competitive advantages: The differences between traditional and emerging industries. Sustainability, 11(551) 1-20. https://doi.org/10.3390/su11020551

Madanat, H., \& Khasawneh, G. (2017). Impact of total quality management implementation on effectiveness of human resource management in the Jordanian banking sector from employee's perspective. Academy of Strategic Management Journal, 16(1), 114-148.

Maduekwe, C., \& Kamala, P. (2016). Performance measurement by small and medium enterprises in Cape Metropolis, South Africa. Problems and Perspectives in Management, 14(2), 43-52. https://doi.org/10.21511/ppm.14(2).2016.05

Mahmood, S., Qadeer, F., \& Ahmad, A. (2015). The role of organizational learning in understanding relationship between total quality management and organizational performance. Pakistan Journal of Commerce and Social Sciences, 9(1), 282-302.

Mahmoud, M., Blankson, C., Owusu-Frimpong, N., Nwankwo, S., \& Trang, T. (2016). Market orientation, learning orientation and business performance: The mediating role of innovation. International Journal of Bank Marketing, 34(5), 623-648. https://doi.org/10.1108/ijbm-04-2015-0057

Mahmud, N., \& Hilmi, M. (2014). TQM and Malaysian SMEs performance: The mediating roles of organization learning. Social and Behavioral Sciences, 130(2014), 216-225. https://doi.org/10.1016/j.sbspro.2014.04.026

Mamun, A., Mohiuddin, M., Fazal, S., \& Ahmad, G. (2018). Effect of entrepreneurial and market orientation on consumer engagement and performance of manufacturing SMEs. Management Research Review, 41(1), 133-147. https://doi.org/10.1108/mrr-04-2017-0102

Mantok, S., Sekhon, H., Sahi, G., \& Jones, P. (2019). Entrepreneurial orientation and the mediating role of organisational learning amongst Indian S-SMEs. Journal of Small Business and Enterprise Development, 26(5), 641-660. https://doi.org/10.1108/JSBED-07-2018-0215. 
Manzoor, F., Wei, L,. Nurunnabi, M., Subhan, Q., Shah, S., \& Fallatah, S. (2019). The impact of transformational leadership on job performance and CSR as mediator in SMEs. Sustainability, 11(2), 436. https://doi.org/10.3390/su11020436

Mehra, S., Rhee, M. (2004). Enhancing educational learning through some TQM principles. International Journal of Quality \& Reliability Management, 21(8), 801-816. https://doi.org/10.1108/02656710410551719

Mehralian, G., Nazari, G., Zarei, L., \& Rasekh, H. (2017). TQM and organizational performance using the balanced scorecard approach. International Journal of Productivity and Performance Management, 66(1), 111-125. https://doi.org/10.1108/ijppm-08-2015-0114

Mgeni, T. (2015). Impact of entrepreneurial leadership style on business performance of SMEs in Tanzania. Journal of Entrepreneurship \& Organization Management, 4(2), 1-9. https://doi.org/10.4172/2169026x.1000142

Miniaoui, H., \& Schilirò, D. (2017). Innovation and entrepreneurship for the diversification and growth of the Gulf cooperation council economies. Business and Management Studies, 3(3), 69-81. https://doi.org/10.11114/bms.v3i3.2594.

Mokhber, M., Khairuzzaman, W., \& Vakilbashi, A. (2017). Leadership and innovation: The moderator role of organization support for innovative behaviors. Journal of Management \& Organization, 24(1), 1-21. https://doi.org/10.1017/jmo.2017.26

$\mathrm{Ng}, \mathrm{H} .$, \& Kee, D. (2018). The core competence of successful owner-managed SMEs. Management Decision, 56(1), 252-272. https://doi.org/10.1108/md-12-2016-0877

Nikraftar, T., \& Momeni, S. (2017). The effects of entrepreneurial orientation, market orientation and learning orientation on performance of ICT business. International Journal of Management Concepts and Pbilosophy, 10(4), 378-391. https://doi.org/10.1504/IJMCP.2017.087263.

Nor-Aishah, H., Ahmad, H., \& Thurasamy, R. (2020). Entrepreneurial leadership and sustainable performance of manufacturing SMEs in Malaysia: The contingent role of entrepreneurial bricolage. Sustainability, 12(8), 1-21. https://doi.org/10.3390/su12083100

Nybakk, E. (2012). Learning orientation, innovativeness and financial performance in traditional manufacturing firms: A higher order structural equation model. International Journal of Innovation Management, 16(5), 1-33. https://doi.org/10.1142/s1363919612003873

Orlitzky, M., Schmidt, F., \& Rynes, S. (2003). Corporate social and financial performance: A meta-analysis. Organization Studies, 24(3), 403-441. https://doi.org/10.1177/0170840603024003910

Pambreni, Y., Khatibi, A., Azama, S., \& Thama, T. (2019). The influence of total quality management toward organization performance. Management Science Letters, 9(9), 1397-1406. https://doi.org/10.5267/j.msl.2019.5.011

Patyal, V. S., \& Maddulety, K. (2015). Interrelationship between total quality management and six sigma: A review. Global Business Review, 16(6), 1025-1060. https://doi.org/10.1177/0972150915597607

Pérez, M., Gutiérrez, P., Agudo, J. (2019). The role of learning orientation in innovation and business performance: A case study in micro, small and medium firms in San Luis Potosi (Mexico). Accounting and Management, 64(1), 1-18.

Peter, F., Adegbuyi, O., Olokundun, M., Peter, A., Amaihian, A., \& Ibidunni, S. (2018). Government financial support and financial performance of SMEs. Academy of Strategic Management Journal, 17(3), 1-10.

Qasrawi, B., Almahamid, S., \& Qasrawi, S. (2017). The impact of TQM practices and KM processes on organisational performance: An empirical investigation. International Journal of Quality \& Reliability Management, 34(7), 1034-1055. https://doi.org/10.1108/ijqrm-11-2015-0160

Ramadhan. M., \& Girgis, M. (2018). Small and medium enterprises in Kuwait: Their impact and the way forward, Volume IV. Kuwait Foundation for The Advancement of Sciences.

Ratnawati, Soetjipto, B., Murwani, D., \& Wahyono, H. (2018). The role of SMEs' innovation and learning orientation in mediating the effect of CSR programme on SMEs' performance and competitive advantage. Global Business Review, 19(35), 1-18. https://doi.org/10.1177/0972150918757842 
The Nexus Between Learning Orientation and Organizational Performance of SMEs

Real, J., Roldán, J., \& Leal, A. (2014). From entrepreneurial orientation and learning orientation to business performance: Analysing the mediating role of organizational learning and the moderating effects of organizational size. British Journal of Management, 25(2), 186-208. https://doi.org/10.1111/i.1467$\underline{8551.2012 .00848 . \mathrm{x}}$

Rhee, J., Park, T., \& Lee, D. H. (2010). Drivers of innovativeness and performance for innovative SMEs in South Korea: Mediation of learning orientation. Technovation, 30(1), 65-75. https://doi.org/10.1016/j.technovation.2009.04.008

Richard, P., Devinney, T., Yip, S., \& Johnson, G. (2009). Measuring organizational performance: Towards methodological best practice. Journal of Management, 35(3), 718-804. https://doi.org/10.1177/0149206308330560

Rogo, H., Shariff, M., \& Hafeez, M. (2017). Moderating effect of access to finance on the relationship between total quality management, market orientation and small and medium enterprises performance: A proposed framework. International Review of Management and Marketing, 7(1), 119-127.

Rojas-Lema, X., Alfaro-Saiz, .J., Rodriguez-Rodrrigez, R., \& Verdecho, M.J. (2020). Performance measurement in SMEs: Systematic literature review and research directions. Total Quality Management and Business Excellence [ahead-of-print]. https://doi.org/10.1080/14783363.2020.1774357

Sahoo, S., \& Yadav, S. (2017). Entrepreneurial orientation of SMEs, total quality management and firm performance. Journal of Manufacturing Technology Management, 28(7), 892-912. https://doi.org/10.1108/jmtm-04-2017-0064

Sahoo, S., \& Yadav, S. (2020). Influences of TPM and TQM practices on performance of engineering product and component manufacturers. 17th Global Conference on Sustainable Manufacturing. Procedia Manufacturing 43(2020), 728-735. https://doi.org/10.1016/i.promfg.2020.02.111

Salge, T., Bohné, T., Farchi, T., \& Piening, E. (2012). Harnessing the value of open innovation: The moderating role of innovation management. International Journal of Innovation Management, 16(03), 1-26.

https://doi.org/10.1142/S1363919612400051

Sattayaraksa, T., \& Boon-itt, S. (2016). CEO transformational leadership and the new product development process: The mediating roles of organizational learning and innovation culture. Leadership \& Organization Development Journal, 37(6), 730-749. https://doi.org/10.1108/lodj-10-2014-0197

Serna, M., Martinez, J. E. V., \& Martinez, J. V. (2016). The impact of learning orientation on innovation and performance in SME's in Mexico. International Review of Management and Business Research, 5(1) 48-64. https://www.irmbrjournal.com/papers/1455098547.pdf

Shariff, M., Raden, A., \& Haroon, H. (2017). Moderating role of access to finance on entrepreneurial orientation, market orientation, learning orientation and SMEs performance of gem and jewelry industry in Thailand: A proposed model. Journal of Business and Social Review in Emerging Economies, 3(1), 109-120. https://doi.org/10.26710/ibsee.v3i1.184

Sila, I. (2018). Country and sector effects on the relationships among TQM practices and key performance measures. International Journal of Productivity and Performance Management, 67(9), 1-38. https://doi.org/10.1108/ijppm-11-2017-0297

Singh, V., Kumarb, A., \& Singh, T. (2018). Impact of TQM on organizational performance: The case of Indian manufacturing and service industry. Operations Research Perspectives, 5, 199-217. https://doi.org/10.1016/j.orp.2018.07.004

Sinha, N., Garg, A., \& Dhall, N. (2016). Effect of TQM principles on performance of Indian SMEs: The case of automotive supply chain. The TQM Journal, 28(3), 338-359. https://doi.org/10.1108/tqm-10-2014-0086

Sinkula, J., Baker, W., \& Noordewier, T. (1997). Framework for market-based organizational learning: Linking values, knowledge, and behaviour. Academy of Marketing Science, 25(4), 305-318. https://doi.org/10.1177/0092070397254003

Stock, R., Six, B., \& Zacharias, N. (2013). Linking multiple layers of innovation-oriented corporate culture, product program innovativeness, and business performance: A contingency approach. Journal of the Academy of Marketing Science, 41(3), 283-299. https://doi.org/10.1007/s11747-012-0306-5 
Sule, J., Ogbadu, E., \& Nafiu, A. (2017). Factor analysis of total quality management adoption by SMEs in Nigeria. Facta Universitatis Series Economics and Organization, 13(4), 365-377. https://doi.org/10.22190/fueo1604365s

Suliyanto, S., \& Rahab, R. (2012). The role of marketing orientation and learning orientation in improving innovativeness and performance of small and medium enterprises. Asian Social Science, 8(1), 134-145. https://doi.org/10.5539/ass.v8n1p134

Taghizadeh, S., Nikbin, D., Alam, M., Rahman, S., \& Nadarajah, G. (2020). Technological capabilities, open innovation and perceived operational performance in SMEs: The moderating role of environmental dynamism. Journal of Knowledge Management, [ahead-of-print] https://doi.org/10.1108/JKM-05-2020-0352

Vij, S., \& Farooq, R. (2015). The relationship between learning orientation and business performance: Do smaller firms gain more from learning orientation? The IUP Journal of Knowledge Management, 13(4), 7-28. https://www.researchgate.net/publication/297849527 The Relationship Between Learning Orientation and Business_Performance_Do_Smaller_Firms_Gain_More_from_Learning_Orientation/citation/dow $\underline{\text { nload }}$

Villaluz, V., \& Hechanova, M. (2019). Ownership and leadership in building an innovation culture. Leadership \& Organization Development Journal, 40(2), 138-150. https://doi.org/10.1108/LODJ-05-2018-0184

Wahab, A., \& Mahmood, R. (2015). Effect of learning orientation and self-efficacy on performance of university leaders: Entrepreneurial leadership as a mediator. Paper presented at the 18th annual convention of Japanese association of administrative science (JAAS) held at Aichi University, Nagoya Campus, Japan, 14-15 November. http://hayalab.com/jaas/

Wolff, J., Pett, T., \& Ring, J. (2015). Small firm growth as a function of both learning orientation and entrepreneurial orientation: An empirical analysis. International Journal of Entrepreneurial Behavior \& Research, 21(5), 709-730. https://doi.org/10.1108/ijebr-12-2014-0221

Xie, X., Wu, Y., \& Zeng, S. (2016). A theory of multi-dimensional organizational innovation cultures and innovation performance in transitional economies: The role of team cohesion. Chinese Management Studies, 10(3), 458-479. https://doi.org/10.1108/CMS-01-2016-0023.

Yabs, J. (2017). Relationship between organizational learning and performance of insurance firms in Kenya. International Journal of Scientific Research and Management. 5(7), 6185-6196. https://doi.org/10.18535/ijsrm/v5i7.47

Yang, C. (2018). The effectiveness analysis of the practices in five quality management stages for SMEs. Total Quality Management and Business Excellence, 31(6), 955-977. https://doi.org/10.1080/14783363.2018.1456010

\section{AUTHORS}

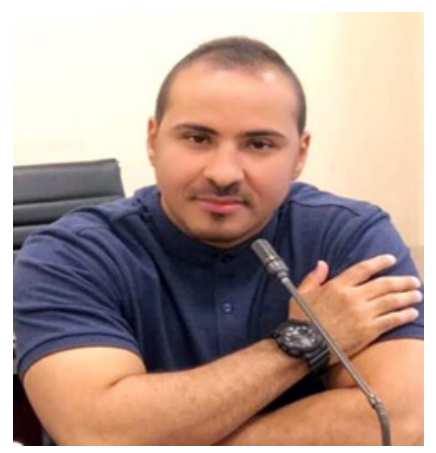

Fahad Awad Aber Sawaean is a third-year PhD student in Management at the Graduate School of Business, Universiti Kebangsaan Malaysia. His research interest is in TQM practices, Innovation Management, Entrepreneurial Leadership and performance measurement. 


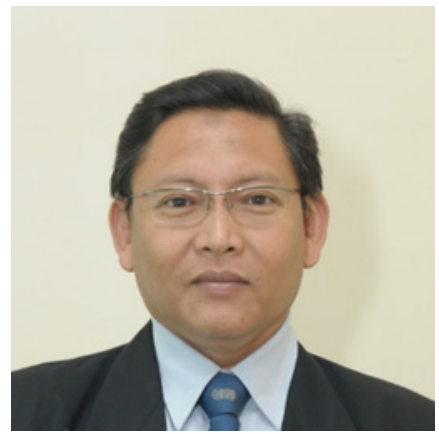

Khairul Anuar Mohd Ali is an Associate Professor at the UKMGraduate School of Business. He received his first degree in Bachelor Business Administration from Washington State University, USA, his Master in Business Administration from Universiti Kebangsaan Malaysia and his PhD from Universiti Utara Malaysia. His current research interests are in the area of quality management, performance measurement and customer satisfaction. His current research project is on the development of Customer Satisfaction Index and Mathematical Modeling for Performance Measurement of Malaysian Local Authorities, both funded by relevant Research Grants. Dr Khairul's research works have appeared in various international refereed journals such as Total Quality Management \& Business Excellence Journal, Quality \& Quantity International Journal, Social Indicators Research Journal, International Review of Business Research Papers, Journal of Global Business Management, Pakistan Journal of Nutrition, The Indonesian Management \& Accounting Research and Jurnal Sains Malaysiana. 